\title{
Analysis of Genotype by Environment Interaction on Cocoa Hybrids (Theobroma cacao L.) Resistance to Phytophthora Pod Rot
}

\author{
Agung Wahyu Susilo ${ }^{1 *}$, Indah Anita-Sari ${ }^{1)}$ and Bayu Setyawan ${ }^{1)}$ \\ ${ }^{1}$ Indonesian Coffee and Cocoa Research Institute, J1. PB Sudirman 90 Jember, Indonesia \\ ${ }^{*}$ Coresponding author: soesiloiccri@yahoo.com \\ Received: 15 October 2016 / Accepted: 22 November 2016
}

\begin{abstract}
Phenomenon of genotype by environment interaction was able to influence the stability performance of cocoa resistance to Phytophthora pod rot (PPR). This research had an objective to evaluate the effect of genotype by environment interaction on resistance of cocoa hybrids to PPR. The tested hybrids were $\mathrm{F}_{1}$ crosses between selected clones of TSH 858, Sulawesi 1, Sulawesi 2, NIC 7, ICS 13, KEE 2 and KW 165. There were 14 tested hybrids and an open pollinated hybrid of ICS 60 x Sca 12 was used as control in multilocation trials at four different agroclimatic locations, namely Jatirono Estate ((highland-wet climate), Kalitelepak Estate (lowland-wet climate), Kaliwining Experimental Station (low land-dry climate) and Sumber Asin Experimental Station (highland-dry climate). Trials were established in the randomized complete block design with four replications. Resistance to PPR were evaluated based on the percentage of infected pod for the years during wet climate of 2010 in Jatirono, Kalitelepak and Kaliwining followed in dry climate of 2011-2015 in Kaliwining and Sumber Asin. Variance of data were analyzed for detecting the effect of genotype by environment interaction (GxE) then visualized with a graph of genotype main effect and genotype by environment interaction (a graph of GGE) biplot. There was consistently no interaction effect between hybrid and location to PPR incidence which was affected by single factor of hybrid, year, location and interaction between year and location. The effect of year indicated yearly change of weather was more important to PPR incidence than location difference. A graph of GGE biplot indicated a stable performance of the tested hybrids among locations.
\end{abstract}

Keywords: interaction, genotype, environment, Theobroma cacao L., Phytophthora pod rot (PPR), hybrid

\section{INTRODUCTION}

Phytophthora pod rot (PPR) caused by the infection of Phytophthora palmivora is the most serious diseases on cocoa in Indonesia, especially in location situated with high humidity (wet climate). Yield losses due to PPR was estimated up to $20-30 \%$ and might result in secondary disease of stem cancer which cause plant die up to $10 \%$ (Guest et al., 2007). Controlling the diseases has been recommended by integrated approach using resistant planting materials, biological or chemical agents and cultural practices (Acebo-Guerrero et al., 2011). The approach of cultural practices was aimed to stabilize environmental condition which is less favorable for the diseases to grow. Resistant planting 
materials should be more effective and durable in addressing the diseases than other approaches but it need a long time process and need more fund for replanting existing farm. Furthermore, strategy on controlling PPR should be directed in short term or long term approaches depend on the level of disease severity.

There are some recommended cocoa planting materials which are resistant to PPR for addressing the diseases such as ICCRI 03, ICCRI 04 (Susilo et al., 2013) and hybrids generated from resistant clones of Sca 6 and Sca 12 (Iswanto \& Winarno, 1992). The genetic factor contributes important resistant expression, however, environmental effect also play significant role on the resistance due to the effect of genotype by environment interaction. It was reported that broadsense heritability of PPR resistance was in moderate category (Susilo et al., 2002; Purwantara et al., 2015) that means the contribution of environment factors was important in affecting the resistance. Air humidity is of the most important environmental condition which directly affecting the growth of $P$. palmivora (Guest, 2007) that yearly environmental change is able to influence the dynamic of PPR resistance. Furthermore, more susceptible plants would be more sensitive to environmental change than resistant ones (Purwantara et al., 2015). This study also reported that intensity of PPR incidence increased higher at the susceptible cocoa from $<20 \%$ during dry season to $46 \%$ during wet season. It is important to understand the phenomenon of genotype by environment interaction on new cocoa varieties to maximize their utilization for controlling PPR.

Breeding for cocoa resistance to PPR were carried out simultaneously in order to improve genetic background of resistant planting materials in Indonesia. The main goal is to develop multigenic of the resistance of high yielding genotype to main diseases such as PPR and vascular-streak dieback (VSD, Ceratobasidium theobromae). Gutiérez et al. (2015) reported the Pound's strategies on cocoa breeding resistance to pest and diseases in Trinidad by using intrecrossing between the wild germplasm and cultivated germplasm to accumulate desirable genes for resistance. Success story on selection the multigenic resistant genotypes on cocoa was reported. The cocoa clone of Sca 6 which having resistance to PPR, VSD and Helopeltis sp. (Susilo et al., 2009) and of the local clones from North Luwu South Sulawesi of MCC 02 which having resistance to VSD, PPR and cocoa pod borer (CPB) (Susilo et al., 2015) both of which may inspiring breeding objectives on developing multigenic resistant on cocoa genotypes to main pests and diseases. Breeding for cocoa resistance to PPR and VSD has been carried out by inter-crossing the selected parental clones which having differences on the disease resistant background and cross compatibility (Susilo et al., 2011). Hybrids of the crosses had been tested in multilocation trials wherein specified with the differences on agro-climatic condition to assess stability performance on PPR resistance referring to resistant hybrid of ICS $60 \mathrm{x}$ Sca 12. It was unknown the effect of genetic by environment interaction ( $\mathrm{G} \times \mathrm{E}$ ) on PPR resistance of the tested hybrid that would be very useful information on developing PPR resistant hybrids as cocoa planting materials. This research was carried out in order to observe the effect of $\mathrm{G} \times \mathrm{E}$ on PPR resistance of some promising hybrids through multilocation trials for releasing the selected hybrids as resistant planting materials. This paper discuss results of the analysis that performing effect of single factors and their interaction of genetic, location and year on PPR resistance as the basis information for utilizing the selected hybrids for farmers. 


\section{MATERIALS AND METHODS}

Genetic materials for multilocation trials were the crosses hybrid between 7 selected clones using factorial design as was reported by Susilo (2011). Trials were established in the randomized complete block design with 4 blocks as replication. There were tested 14 hybrids ( $\mathrm{F}_{1}$ and reciprocal crosses) and an open pollinated hybrid of ICS 60 x Sca 12 was used as control. Seedlings of the tested hybrids were derived by hand pollination crossing system at Kaliwining Experimental Station of Indonesian Coffee and Cocoa Research Institute (ICCRI) in Jember wherein situated in $45 \mathrm{~m}$ above sea level (asl.) and D type of climate according SchmidtFerguson classification.

Multilocation trials were carried out at four different agroclimatic locations, namely Kaliwining Exp. Station of ICCRI in Jember (low land - dry climate), Sumber Asin Experiment Station of ICCRI in Malang (high land-dry climate), Jatirono Estate in Banyuwangi (high land-wet climate) and Kalitelepak Estate in Banyuwangi (low land-wet climate). Trials used different number of sample trees per plot as limited land area, such as 16 trees in Kaliwining, 28 trees in Sumber Asin, 24 trees in Jatirono and 20 trees in Kalitelepak. The trees were planted in 2002/2003 and maintained according to good agricultural practices in planting distance of $3 \mathrm{~m} \mathrm{x} 3 \mathrm{~m}$ under shade trees of lamtoro (Leucaena glauca), coconut (Cocos nucifera) and Glyricideae sp.

Evaluation the resistance to PPR was carried out by assessing the number of infected pod per plot basis in monthly interval during the year of time assessment. The assessment were conducted during wet climate of 2010 wherein situated with wet condition due to high rainfall all the year that supporting optimal growth of Phytophthora fungus in three locations of Kalitelepak, Jatirono and
Kaliwining then the data were classified derived during wet climate. Further assessments were followed in Kaliwining and Sumber Asin as the representative dry area during the year of 2011-2015 then the data were classified derived during dry climate.

The recorded data were performed to the combined analysis of variance to investigate the effect of genotype (hybrid), location, years and their interaction. Means were differentiated by Duncan multiple range test (DMRT) at $95 \%$ of significant level. Intepretation of genotype by environment interaction was also supported by a graph of GGE biplot (genotype main effect and genotype by environment interaction) refer to Yan \& Kang (2003).

\section{RESULTS AND DISCUSSION}

Results of combined-analysis of variance for PPR intensity showed significant effect of hybrid, year and interaction between hybrid and year but there was no significant effect of the interaction between hybrid and location (Table 1 and 2). Data recorded in 2010 showed that wet condition in the field due to heavy rain during all the year which was favorable for PPR growth, maximally influenced field infection of PPR to the plant. Therefore, it could be interpreted that the resistance of tested hybrids to PPR was not just affected by genetic factor but also by yearly environmental change due to significant effect of year to PPR intensity. The micro-climate change was mostly affected by annual rainfalls that influence air humidity in the field. There were consistently no significant effect of the interaction between hybrid and location to PPR intensity indicating that the strains of $P$. palmivora were very similar in their pathogenicity between locations that effected in no difference on PPR incidence. This was supported by previous report that 
genetic diversity of $P$. palmivora was low (Purwantara \& Umayah, 2010; Saul-Maora et al., 2016; Surujdeo-Maharaj et al., 2016). The different location effect was influenced by climate differences which mostly divided into wet and dry.

Intensity of PPR incidence was significantly various among tested hybrids (Table 3 ) performing any difference in their resistance. Mean of PPR incidence intensity of these hybrids recorded in wet climate of 2010 was varied between $35.7-55.7 \%$ which was higher than in dry climate of 2011-2015 between 17.7-24.9\%. In general, intensity of PPR incidence was two times higher in wet climate of 2010 (43.98\%) than in dry climate of 2011-2015 (20.85\%). The high PPR intensity indicate highest level of PPR susceptibility of the tested hybrids was similar to the previous report by Purwantara et al. (2015) which showed the highest level of PPR intensity on susceptible clones was $46 \%$. Others report by McMahon et al. (2010) supported this result which classified PPR resistance in four categories, which were resistant $(<15 \%)$, moderate resistant (15-24\%), moderate susceptible (25-34\%) and susceptible (>34\%). Refering to this classification therefore the resistance of tested hybrid to PPR was moderate resistant in dry climate and susceptible in wet climate.
These tested hybrids which having lower intensity of PPR incidence can be supposed to perform better resistance to $P$. palmivora. Suhendy et al. (2004) reported that the resistant clones of Sca 12 and KEE 2 have good combining ability for PPR resistance therefore hybrids generated by those resistant clones would be more resistant on the contrary this results indicate the tested hybrids inherited by using KEE 2 both as male or female performed less resistance to PPR than hybrids generated by susceptible clones such as TSH 858 and Sulawesi 1 (Table 4). This result confirms that KEE 2's combining ability for PPR resistance may be less compatible to the parental clones used in this study. The inheritance of PPR resistance was reported as additive and polygenic (Flamet et al., 2001 cit. Guest, 2007) moreover Barreto et al. (2015) that reported the PPR resistance was inherited in olygogenic manner that breed for resistant genotypes to PPR should be inter-cross between resistant clones. de Cássia-Bahia et al. (2015) also confirmed this phenomenon on PPR resistance inheritance in which to breed PPR resistance hybrids were done by crossing between both resistant parental clones of Sca 6 and Catango.

This results consistently perfomed no significant effect of the interaction between hybrids and location to PPR resistance assessed

Table 1. Analysis of variance of the intensity of Phytophthora pod rot (PPR) incidence on cocoa hybrids evaluated under multilocation trials in Kaliwining and Sumber Asin during 2011-2015

\begin{tabular}{|c|c|c|c|c|}
\hline Sources of variation & Degree of freedom & Sum of square & Mean sum of square & $\mathrm{F}_{\text {cal. }}$ \\
\hline Block & 3 & 65 & 22 & $4.62^{*}$ \\
\hline Hybrid & 14 & 166 & 12 & $2.52^{*}$ \\
\hline Year & 4 & 2,956 & 739 & $156.53^{* *}$ \\
\hline Location & 1 & 1,556 & 1,556 & $329.61^{*}$ \\
\hline Hybrid x year & 56 & 414 & 7 & $1.57^{*}$ \\
\hline Hybrid $\mathrm{x}$ location & 14 & 91 & 6 & 1.37 ns \\
\hline Year $\mathrm{x}$ location & 4 & 5,161 & 1,290 & $273.29^{*}$ \\
\hline Hybrid $\mathrm{x}$ year $\mathrm{x}$ location & 56 & 413 & 7 & $1.56^{*}$ \\
\hline Error & 447 & 2,110 & 5 & \\
\hline Total & 599 & 12,933 & & \\
\hline
\end{tabular}


Table 2. Analysis of variance of the intensity of Phytophthora pod rot (PPR) incidence on cocoa hybrids evaluated under multilocation trials at Jatirono, Kalitelepak and Kaliwining during wet climate of 2010

\begin{tabular}{lcccc}
\hline Sources of variation & Degree of freedom & Sum of square & Mean sum of square & $\mathrm{F}_{\text {cal. }}$ \\
\hline Block & 3 & 483 & 161 & $1.38^{\mathrm{ns}}$ \\
Hybrid & 14 & 4,879 & 349 & $2.98^{* *}$ \\
Location & 2 & 70,787 & 35,393 & $302.34^{* *}$ \\
Location x hybrid & 28 & 3,630 & 130 & $1.11^{\text {ns }}$ \\
Error & 132 & 15,453 & 117 & \\
Total & 179 & 952,311 & & \\
\hline
\end{tabular}

Note : Fisher test indicate significant ${ }^{*)}$ at $\alpha=5 \%,{ }^{* *)}$ at $\alpha=1 \%$ and ${ }^{\text {ns) }}$ not significant.

Table 3. Intensity of PPR incidence (\%) of the tested hybrids assessed through multilocations trials during dry and wet climate

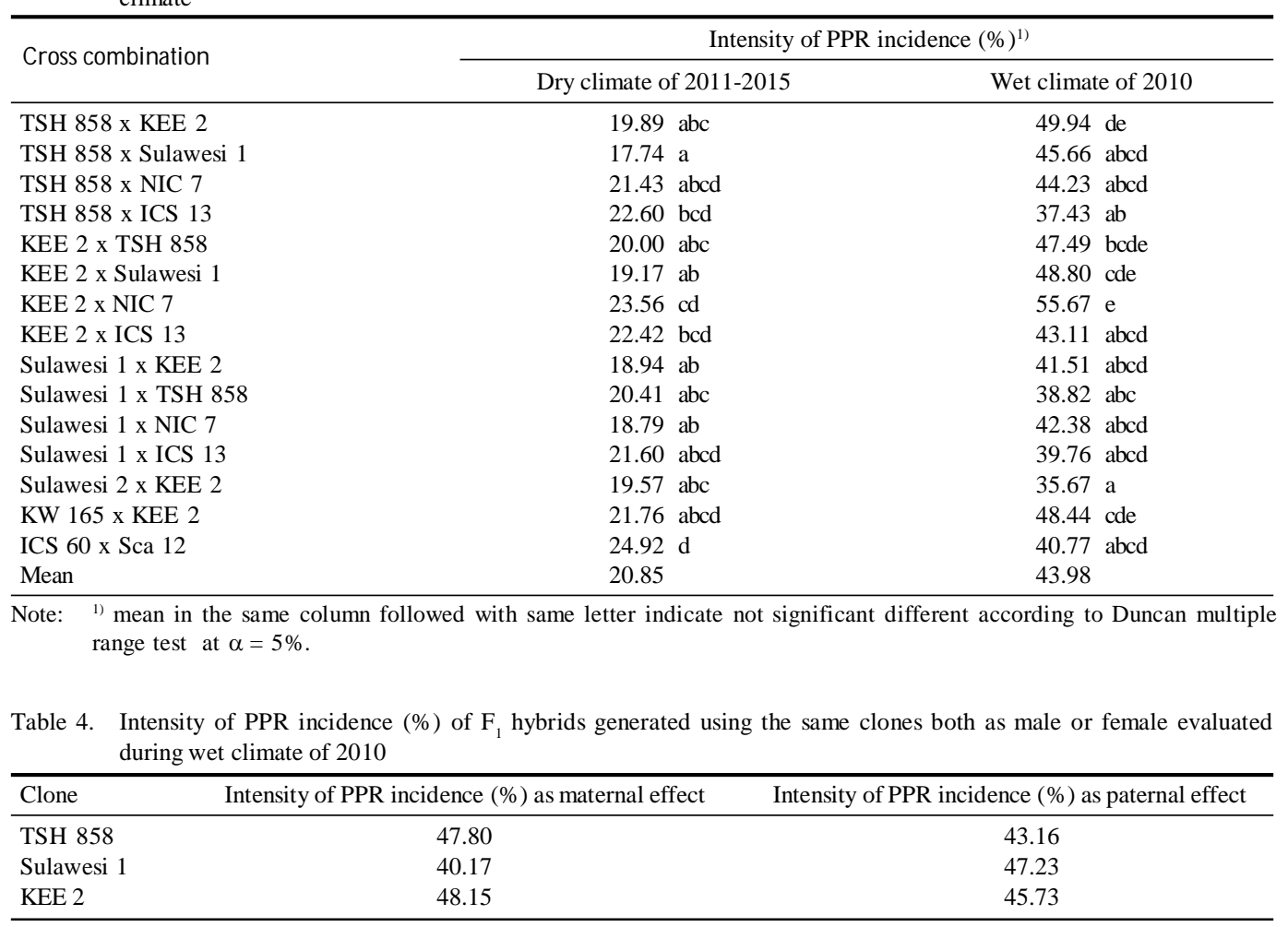

at two different enviromental conditions (wet and dry climate) (Table $2 \& 3$ ). Furthermore, genetic expression of the tested hybrids for PPR resistance were stable among locations as the differences on PPR resistance were due to micro-environment change and not affected by pathogenic differences of the fungus. In this case, air humidity was the environmental conditions most favoring for the fungus growth. Graph of GGE biplot visualize stability performance of the tested hybrids, in which most of the hybrids that were assessed during wet climate closely positioned at the axis point indicating their stable performance among locations. Therefore, differences in intensity of PPR incidence among hybrids would depend on microenvironment change such as air humidity which supported the epidemic rather than plant resistance or pathogenicity of the fungus as the fungus relativeness were quite similar (Purwantara \& Umayah, 2010).

GGE biplot (Figure 1A) visualize the differences of PPR intensity among locations where in Kaliwining situated in dry climate performed high intensity of PPR 


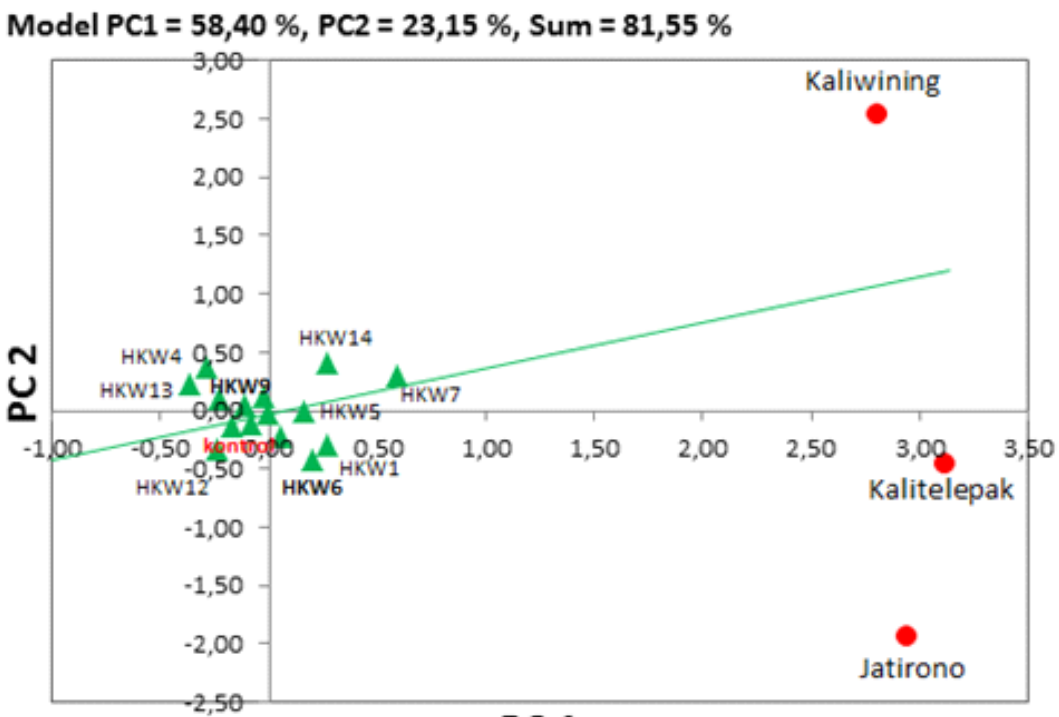

PC 1

Model PC1 $=36,67 \%$, PC2 $=16,95 \%$, Sum $=53,63 \%$

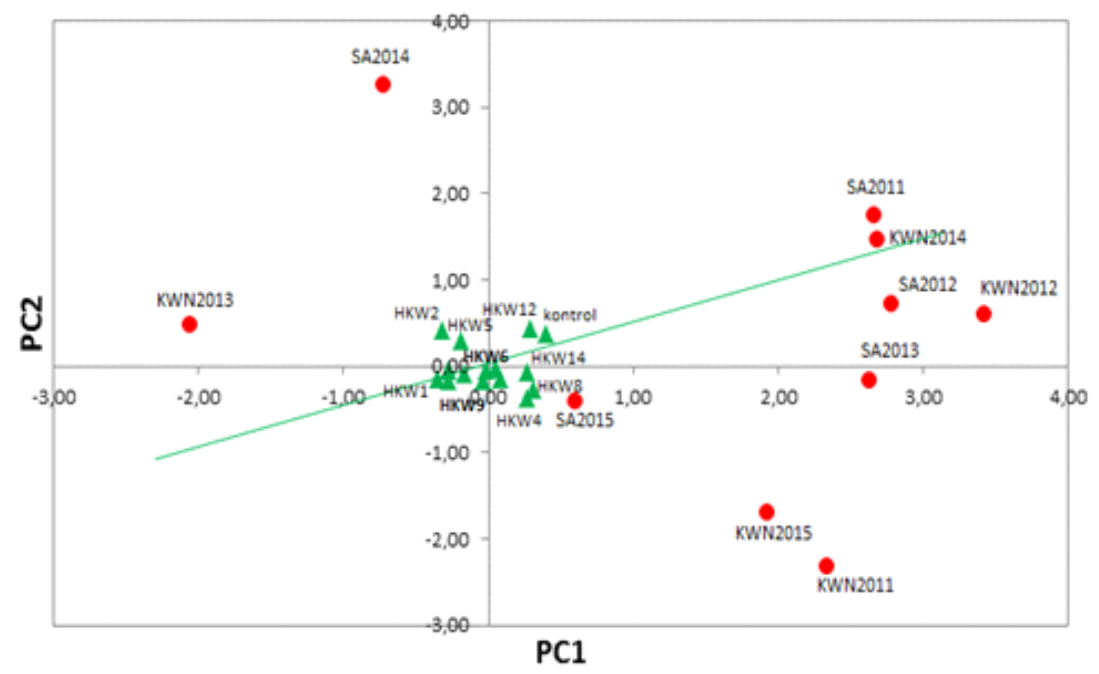

Note: HKW 1 (TSH 858 x KEE 2), HKW 2 (TSH 858 x Sulawesi 1), HKW 3 (TSH 858 x NIC 7), HKW 4 (TSH 858 x ICS 13), HKW 5 (KEE 2 x TSH 858), HKW 6 (KEE 2 x Sulawesi 1), HKW 7 (KEE 2 x NIC 7), HKW 8 (KEE 2 x ICS 13), HKW 9 (Sulawesi 1 x KEE 2), HKW 10 (Sulawesi 1 x TSH 858), HKW 11 (Sulawesi 1 x NIC 7), HKW 12 (Sulawesi 1 x ICS 13), HKW 13 (Sulawesi 2 x KEE 2), HKW 14 (KW 165 x KEE 2) and control (open pollination ICS $60 \mathrm{x}$ Sca 12). KWN 20xx = Kaliwining 20xx; SA 20xx = Sumber Asin 20xx

Figure 1. GGE biplot of intensity of PPR incidence of the tested hybrids evaluated during wet climate of 2010 in three locations (A) and followed at dry climate of 2011-2015 in two locations (B) 
incidences during wet climate of 2010. This result confirmed that micro-environment significantly affected PPR growth that environmental change of dry area (in which performed by Kaliwining location) possibly was better for favoring PPR intensity when air humidity very suitable for the fungus growth. McMahon et al. (2015) reported that the intensity of PPR incidence was significantly affected by the total of rainfall in monthly basis. However, further study reported by Surujdeo-Maharaj et al. (2016) informed that to complete its life cycle, P. palmivora also needed dry condition for spore dispersal and infection process. The zoospora growth also need a dry condition at least for 2030 minutes (Guest, 2017). Furthermore the dry area would be more suitable for PPR growth when micro-environment condition match properly to the requirement condition of the PPR life cycle.

This result reconfirmed that performance of cocoa resistance to PPR in the field is not just affected by genetic of the plant but also by environmental condition of micro-environment change which would depend on the volume of rainfall and its distribution in monthly basis. Furthermore, the efforts to address PPR there should be able to combine integrated approach between resistant planting material with cultural practices to manage micro-environment in the location to be less favorable for PPR growth. This result indicate that the tested hybrids performed moderate resistance to PPR that development of the selected hybrid had to be combined integrally with other practical control especially cultural practices such as pruning heavy branches to reduce air humidity for suppressing PPR incidence.

\section{CONCLUSION}

The intensity of PPR incidence on cocoa hybrids was affected by genetic factor and microenvironment change expressed by the significant effect of year and there was no significant effect of the interaction between hybrids and locations. Mean differences of the intensity of PPR incidence among tested hybrids indicated moderate resistance to PPR in which the resistance would be affected by genetic effect and micro-environment change year by year but not affected by the specified locations.

\section{ACKNOWLEDGEMENT}

The authors wish to thank Director of ICCRI for his permission on publishing this paper. We wish also to thank the managers of Kalitelepak Estate and Jatirono Estate of PTPN XII for their support in the facilitation of the multilocation trials. The success on implementing this research was also supported by the head of Kaliwining Experimental Station and Sumber Asin Experimental Station of ICCRI and the technicians of Plant Breeding Laboratory of ICCRI, especially thanks to Rudi Hartoyo and Sukarmin for their technical assistance.

\section{REFERENCES}

Acebo-Guerrero, Y.; A. Hernández-Rodríguez; M. Heydrich-Pérez; M. El Jaziri \& A.N. Hernández-Lauzardo (2011). Management of black pod rot in cacao (Theobroma cacao L.): A review. Fruits, 67, 41-48.

Barreto, M.A.; J.C.S. Santos; R.X. Corrêa; E.D.M.N. Luz; J. Marelli \& A.P. Souza (2015). Detection of genetic resistance to cocoa black pod disease caused by three Phytophthora species. Euphytica, 206, 677-687.

de Cássia Bahia, R.; C.I. Aguilar-Vildoso; E.D.M. Newman Luz; U.V. Lopes; R.C.R. Machado \& R.X. Corrêa (2015). Resistance to black pod disease in a segregating cacao tree population. Tropical Plant Pathology, 40, 13-18. 
Guest, D. (2007). Black pod: Diverse pathogens with a global impact on cocoa yield. The American Phytopathological Society, 97, 1650-1653.

Gutiérrez, O.A.; A.S. Campbell \& W. PhillipsMora (2016). Breeding for disease resistance in cacao. p. 567-609. In: B.A. Bailey \& L.W. Meinhardt (Eds.). Cacao Diseases. Springer International Publishing Switzerland.

Iswanto, A. \& H. Winarno (1992). Cocoa breeding at RIEC Jember and the role of planting material resistant to VSD and black pod. p. 163-169. In: P.J. Keane \& C.A.J. Putter (Eds.). Cocoa Pest and Disease Management in Southeast Asia and Australasia. Food and Agriculture Organization of The United National, Rome, Italy.

Keane, P.; P. McMahon; D. Guest \& S. Lambert (2008). Project Final Report: Selection for Improved Quality and Resistance to Phytophthora Pod Rot, Cocoa Pod Borer and Vascular-Streak Dieback in Cocoa in Indonesia. ACIAR, Canberra ACT 2601, Australia.

McMahon, P.; A. Purwantara; A.W. Susilo; Sri-Sukamto; A. Wahab; H. Purung; M. Hidayat; D. Ismail; Taproni; S. Lambert; D. Guest \& P. Keane (2010). On-farm selection for quality and resistance to pest/diseases of cocoa in Sulawesi: (ii) Quality and performance of selections against Phytophthora pod rot and vascular-streak dieback. International Journal of Pest Management, 56, 351-361.

McMahon, P.; H. Purung; S. Lambert; S. Mulia; Nurlaila; A.W. Susilo; E. Sulistyowati; Sri-Sukamto; M. Israel; A. Saftar; A. Amir; A. Purwantara; A. Iswanto; D. Guest \& P. Keane (2015). Testing local cocoa selections in three provinces in Sulawesi: (i) Productivity and resistance to cocoa pod borer and Phytophthora pod rot (black pod). Crop Protection, 70, 28-39.

Purwantara, A. \& A. Umayah (2010). Analisis keragaman genetik Phytophthora palmivora dari tanaman kakao di
Indonesia menggunakan AFLP. Menara Perkebunan, 78, 61-69.

Purwantara, A.; P. McMahon; A.W. Susilo; SriSukamto; S. Mulia; Nurlaila; A. Saftar; H. Purung; S. Lambert; P. Keane \& D. Guest (2015). Testing local cocoa selections in Sulawesi: (ii) Resistance to stem canker and pod rot (black pod) caused by Phytophthora palmivora. Crop Protection, 77, 18-26.

Saul-Maora, J; E.C.Y. Liew \& D.I. Guest (2016). Limited morphological, physiological and genetic diversity of Phytophthora palmivora from cocoa in Papua New Guinea. Plant Pathology, 65, 1-7.

Suhendy, D.; A.W. Susilo \& S. Mawardi (2004). Analisis daya gabung beberapa klon kakao untuk sifat ketahanan terhadap penyakit busuk buah (Phytophthora palmivora (Butl.)). p. 423-428. In: A. Kasno; D.M. Arsyad; J. Purnomo; Kuswanto; M.M. Adie; M. Anwari; N. Mugrahaeni; N. Basuki; Rustidja; St. A. Rahayuningsih; Suwarso \& Trustinah (Eds.). Dukungan Pemuliaan Terhadap Industri Perbenihan pada Era Pertanian Kompetitif. Perhimpunan Ilmu Pemuliaan Indonesia bekerjasama dengan Balai Penelitian Tanaman Kacang-kacangan dan Umbi-umbian. Malang.

Surujdeo-Maharaj; T.N. Sreenivasan; L.A. Motilal \& P. Umaharan (2016). Black Pod and Other Phytophthora Induced Diseases of Cacao: History, Biology, and Control. p. 213-266. In: Bryan A. Baley \& L.W. Meninhard (Eds.). Cocoa Diseases. Springer International Publishing. Switzerland.

Susilo, A.W.; D. Suhendi; A.A. Prawoto \& SriSukamto (2002). Ragam genetik ketahanan tanaman kakao terhadap Phytophthora palmivora (Butl.). Pelita Perkebunan, 18, 1-9.

Susilo, A.W.; S. Mawardi \& Sudarsianto (2009). Keragaan dayahasil klon kakao (Theobroma cacao L.), Sca 6 dan DRC 15 tahan penyakit pembuluh kayu. Pelita Perkebunan, 25, 76-85. 
Susilo, A.W. \& I. Anita-Sari (2011). Respons ketahanan beberapa hibrida kakao (Theobroma cacao L.) terhadap serangan penyakit pembuluh kayu (vascular-streak dieback). Pelita Perkebunan, 27, 77-87.

Susilo, A.W. (2011). Analisis stabilitas dayahasil beberapa hibrida unggul harapan kakao (Theobroma cacao L.). Pelita Perkebunan, 27, 168-180.

Susilo, A.W.; I. Anita-Sari \& S. Mawardi (2013). Seratus tahun pemuliaan kakao di Indonesia. p. 110-121. In: T. Wahyudi; J.B. Baon; S. Abdoellah; Misnawi \& A.W. Susilo(Eds.). Prosiding Simposium Kakao 2012, Padang 5-8 November 2012.
Susilo, A.W.; I. Anita-Sari \& Imran (2015). Yield performance of locally selected cocoa clones in North Luwu. Pelita Perkebunan, 31, 152-162.

Yan, W. \& M.S. Kang (2003). GGE Biplot Analysis: A Graphycal Tool for Breeders, Geneticist, and Agronomists. CRC Press LLC 2000, N.W. Corporate Blvd Boca Raton, Florida.

$$
* * 0 * *
$$

